\title{
Affecting Factors on Accountability of Village Fund Allocation Management in Bogor District
}

\author{
Fajar Rahmatulloh, Khoirul Aswar, Ermawati \\ Universitas Pembangunan Nasional Veteran Jakarta, Indonesia \\ fajarrahmatulloh13@gmail.com
}

\begin{abstract}
This research aims to find out factors on the accountability of village fund allocation management in Bogor district. Population in this research was village heads and village secretaries in Bogor district. The hypotheses were tested using data surveys from 77 respondents. The analysis technique used multiple linear regression. The findings from this research indicated that the competence of village officials positively significant on the accountability of village fund management. Whereas, society participation and supervisors had no relationship with accountability in the management of village fund allocations. This research contributed to the use of village fund allocations in the Indonesian village government. The further research should the interview method to dig deeper into the management of village funds. In addition, further research is expected to expand research to not be only focused on villages in Bogor District.
\end{abstract}

Keywords: Village official competence, Society participation, Supervision, Accountability of village fund allocation management.

\section{Introduction}

Village is an area inhabited by group of people who have government system according to statutory provisions in force. On January 15 $5^{\text {th }}, 2014$ the government enacted Law (UU) No. 6 Year 2014 concerning villages. It states that villages has their rights in regulating and managing the interests of local communities and playing a role in realizing the ideals of independence. The granting of broad, real and responsible authority in the laws and regulations is the planning of the democratization process in the implementation of village autonomy to assist the central government in conducting government in villages with a heavy emphasis on district/city governments. The factual empirical situation is a balance of the implementation of village autonomy based on Law (UU) Number 5 Year 1974 and the previous regulations. Furthermore, (Permendagri No. 20 2018) states that village fund management conduced by village officials is expected to be able to realize community development and increase village development.

The village budget needs to be managed properly so that there is no authority. The obstacles that arise in the accountability of village fund management from previous research, such as Aziz (2016) are the lack of awareness of village community participation and the lack of human resource capacity in government. In addition, success in village development is affected by several factors, which are: society participation, competence of village officials and supervision (Nurjaman, 2015). Village financial management is all activities which include planning, implementing, administering the issuance, and accountability for village finances. Village finance is managed based on the principles of transparency, accountability, participation and it is carried out in an orderly and budgetary discipline. In 2015 to September 2018 though supervision result of Indonesia Corruption Watch (ICW) in Indonesia in Table 1.

Table 1: Corruption Cases of Village Funds

\begin{tabular}{lll}
\hline Cases & Suspected & Loss \\
\hline 181 & 184 & $40,600,000,000$ \\
\hline
\end{tabular}

Based on the Table 1 it show that there was an increase in corruption cases of village funds in Indonesia these results indicate that the country suffered a loss of Rp 40,600,000,000 and there were also 184 suspected corruption cases out of 181 cases in Indonesia. This corruption was carried out from the budget planning process to the evaluation stage. ICW considered that the case of corruption of village funds occurred due to various factors, such as the lack of competence of village officials, lack of community participation and also lack of supervision (www.kompas.com). The research conducted by Thomas (2013) showed that the lack of competence of village officials is an obstacle in managing village funds. Furthermore, Cheng, Engstrom and Kattelus, (2002) in Yamin and Ishak (2018) mentioned that the competencies possessed by government officials can affect the accountability of village governments. Previous researches found that the competence of village officials had a significant. 
Positive effect on the accountability of village fund management (Atmadja \& Saputra, 2018; Budiana, Said \& Nursini, 2019; Dewi \& Gayatri, 2019; Santoso, 2016; Putra \& Rasmini, 2019). In addition, the research found that it had no effect as the research conducted by Widyatama, Novita and Diarespati (2017). Community participation can be one of the factors which determine the effectiveness of village fund management. Research by Naimah (2017), Putra and Rasmini (2019), Umaira and Adnan, (2019) found an effect between community participation toward the accountability of village fund management. Other factors which can determine the effectiveness of village fund allocation is supervision. Researched by Umaira and Adnan (2019), Atmadja and Saputra (2018), Munti and Fahlevi (2017) found a positive and significant relation between supervision of accountability in village fund allocation management. Based on the explanation above, the purpose of this research is to examine and analyze whether the competence of village officials, community participation and supervision affect the accountability of village fund allocation management.

\section{Theoretical Perspective}

Agency Theory: This research used theory agency. The theory explains the relation between management of companies which have the authority to manage the resources of the company that is being run. According to Pepper and Gore (2015), it states that agency theory focuses on the cost of conflicts which occur toward the perpetrators of agent funds. Meanwhile, according to Homayoun (2015), it also explains agency theory also between agents and parties who work together to achieve goals in the division of labor. Related to the accountability of village funds, the theory of money had been used by previous researches, such as Dewi and Gayatri (2019) and Faristina (2011). Agency theory based on (Panda \& Lepsa, 2017) is focused on separating power between principals and agents and finding solutions to problems which arise in an organization. Research conducted by Dewi and Gayatri (2019) used agency theory in recognizing the differences between principal and agent. Thus, the differences can be minimized through adequate competence of village officials, leadership to the village and community participation. The results of this research are useful for the input of village governments in the Abang District in an effort to realize accountability in village fund management.

The Effect of Village Official Competence on Accountability of Village Fund Allocation Management: The gab between government and society is used by agency theory. Agencies must be able to be transparent and willing to be monitored by the community in relation to what is conducted. Village officials must have the ability to manage the existing budget. Village officials have great competence. Thus, it will be very supportive to know the regulations related to village fund management. Previous research found that village apparatus competence affects the accountability of village fund allocation management (Aziiz \& Prastiti, 2019; Dewi \& Gayatri, 2019; Indrajaya, 2017: Mada, et al., 2017: Tarjo, 2019; Zirman, Edvan \& Rozi, 2010). Based on the arguments and descriptions above, a hypothesis can be formulated as follow:

H1: Competence of village officials significantly influences the accountability of village fund allocation management.

The Effect of Society Participation on Accountability of Village Fund Allocation Management: In managing village fund, society plays the important role to supervise the activities of village government. This is based on agency theory which explains that principals and agents have differences and interests. Agents will not get a guarantee that they always conduct in accordance with principal interests. The statement is also expected that the community can supervise directly from the planning stage to the management stage. The research of Dewi and Gayatri (2019) Umaira and Adnan (2019) examined community participation in accountability for managing village fund allocations. The results of previous research suggested that community participation has a significant effect on accountability in managing village fund allocations. Based on the description above, the hypothesis can be formulated as follow:

H2: Society participation significantly influences the accountability of village fund allocation management.

The Effect of Supervision on Accountability of Village Fund Allocation Management: Siagian (2002) states that supervision is an organization activity conducted from the observation process until the implementation stage to ensure. All tasks is carried out according to plan. The government supervision can improve financial accountability by evaluating and improving internal control, risk management and governance processes "(Aikins, 2011). Supervision is carried out starting from the planning stage to the accountability stage carried out to achieve the principle of accountability in the management of village 
funds in order to avoid irregularities. Thus, management is carried out effectively and efficiently. Based on the arguments above, it can be concluded that supervision will increase the accountability of village fund management. Related to supervision, previous researched of Umaira and Adnan (2019), Munti and Fahlevi (2017) Atmadja and Saputra (2018) found that supervision affect the accountability of village fund allocation management. Based on the description above, the hypothesis can be formulated as follow: H3: Supervision has a significant influences the accountability of village fund allocation management.

Figure 1: Research Framework

\begin{tabular}{|c|c|}
\hline $\begin{array}{c}\text { Competence of Village } \\
\text { Official }\end{array}$ & \\
\hline Society Participation & $\begin{array}{c}\text { Accountability of Village Fund } \\
\text { Allocation Management }\end{array}$ \\
\hline Supervision & \\
\hline
\end{tabular}

\section{Research Method}

Analysis technique used in this research was multiple linear regressions. Multiple linear regression is an analysis used to partially examine the competency variables of village officials, community participation and oversight of the accountability for managing village fund allocations. This research used a tool to test and process data used SPSS software version 25. The sample consisted of population, consisting of the number of members selected from unlimited. This research samples were 77 villages with a total sample of $77 \times 2=154$ total sample. Sampling used cluster sampling method. Variables in this study are accountability, competence, community participation and supervision. Accountability is the rules relating to transparency and accountability and participation in the management of village fund allocations. Accountability of village fund management was measured using two dimensions consisting of: honesty and legal process.

Indicators were adopted from Tarjo's study (2019) with modifications. Furthermore, competence is a good understanding in conducting work. It is about having skill and attitude in implementing work. Competence uses two dimensions which are the ability of knowledge and attitude. The indicator adopts research from Tarjo (2019) with some modifications. Community participation is a measuring tool for obtaining information about needs, attitudes in development activities through the preparation and planning of the general public. Community participation in this research was measured using questions adopted from Haller 1984, and Sujarweni (2015). Supervision is a process of a thorough examination of a government activity with the aim of such activities being carried out in accordance with applicable laws. Supervision is measured by adopting an Anugriani (2014) study with modifications.

\section{Results and Discussion}

Based on screening process of respondent based on determined before, it used cluster sampling. There were 7 sub-districts in Bogor district with a total sample of 86 questionnaires which will be used in this research from a total of 154 questionnaires distributed. Samples used in this research were 86 questionnaires with 2 respondents and questionnaires issued because outlier indicated 9 questionnaires. The research had the gender category of the respondent. There were 79 men respondents who filled in with $91.9 \%$ and 7 women respondents who filled out the questionnaire with a percentage of $8.1 \%$. These results indicated that more village heads and village secretaries were respondents in this research. There were respondents who answered questionnaires with a high school education level of 71 respondents with a percentage of $82.6 \%$ whose level of education was diploma (D3) of 6 respondents with a percentage of $7.0 \%$ of respondents.

Whose final education level was S1 as many as 9 respondents with a percentage of $10.5 \%$ and S2 as many as 0 respondents with a percentage of $0 \%$, the results showed that there were more village heads and village secretaries with high school education as respondents in Bogor District. The research had a longstanding category of Village Head and Village Secretary. There were 30 respondents with a term of office 
of 1 year with a percentage of 34.9\%, 15 respondents with a term of office of 2 years $17.4 \%$ with a percentage of $17.4 \%$, and 5 respondents with a term of office of 3-4 years with a percentage of $5.8 \%$, 36 respondents with 5 years of service with $41.9 \%$ percentage. This result showed that there were more village heads and village secretaries who had served five years long.

Table 2: The Summary of Reliability Test

\begin{tabular}{llll}
\hline Variable & & Question Number & Cronbach's Alpha \\
\hline Accountability of Village Fund & Allocation & 6 & 0.648 \\
Management & & \\
The competence of village officials & 6 & 0.705 \\
Society participation & 4 & 0.760 \\
Supervision & 6 & 0.721 \\
\hline
\end{tabular}

Validity test of research variable used pearson correlation. Reliability tests were carried out to measure the internal consistency of items on the instrument. Reliability is the extent to which measurements are reliable or consistent when measured at different time points (Sekaran \& Bougie, 2013). Generally, the Cronbach alpha coefficient is used among researchers to test the consistency between research instrument items. In this view, the Cronbach alpha coefficient was also used in this study to examine the internal consistency of items on the research instrument. A higher Cronbach alpha value is usually needed for a group of items which measure the same variable. Most researches recommend that Cronbach's alpha should be greater or equal to 0.70 , but values of 0.60 to 0.70 are also considered acceptable (Sekaran \& Bougie 2013) Table 2 presents a summary of the reliability test for all variables from 0.648 to 0.760 . It has exceeded the acceptable minimum threshold of 0.6 and as such, the steps are reliable.

Table 3: Results of Determination Coefficient Test $\mathbf{R}^{2}$

\begin{tabular}{lllll}
\hline Model & R & R Square & Adjusted R Square & Std. Error of the Estimate \\
\hline 1 &, $311^{\text {a }}$ &, 097 &, 060 & 2,28201 \\
\hline
\end{tabular}

It is known the determination coefficient showed by Adjusted Rsquare value of 0.060 or $6 \%$. This means that, $6 \%$ of the accountability for managing village fund allocations can be explained by the competence of village officials, society participation and supervision. While the remaining $94.6 \%$ accountability for managing village fund allocations can be explained by other variables not used in this research such as village head leadership, technology utilization, organizational commitment and others.

Table 4: Results of $t$ Statistic Test

\begin{tabular}{lllllll}
\hline \multicolumn{5}{c}{ Model } & & \multicolumn{5}{l}{ Unstandardized Coefficients } & $\begin{array}{l}\text { Standardized } \\
\text { Coefficients }\end{array}$ & & \\
\cline { 3 - 5 } & & B & Std. Error & Beta & t & Sig. \\
\hline 1 & (Constant) & 19,121 & 5,440 & & 3,515 &, 001 \\
& KPD &, 388 &, 164 &, 278 & 2,359 &, 021 \\
& PM &,- 046 &, 118 &,- 041 &,- 391 &, 697 \\
& P &, 220 &, 125 &, 199 & 1,751 &, 084 \\
\hline
\end{tabular}

The Effect of Village Official Competence on Accountability of Village Fund Allocation Management: The first hypothesis in this research states that the competence of village officials affected the accountability in the management of village fund allocation. After conducting the t statistical test, it was obtained a t-count of 2.359 with a table of 1.993. Thus, tcount $>$ ttable $(2.359>1.993)$ with a significance level of less than $0.05(0.021<0.05)$. Thus, Ha was accepted. It can be concluded that the competence of the large apparatus has a significant effect on the accountability of village fund allocation management. These results illustrated that the village head must be able to compile and implement the specified village budget funds, master village financial management, the level of education influences the implementation of tasks, education owned by village human resources and village financial management. Thus, it will be able to increase accountability in the management of village fund allocation. In line with previous research conducted in villages of Abang Sub-district, it stated that the competence of village officials had a positive effect toward accountability in managing village fund allocations (Dewi, Gayatri 2019). Yamin and Ishak (2018) mentioned that the competencies possessed by government officials could affect the accountability of village governments. 
The same thing was also found in Enrekang village conducted by Budiana, Said and Nursini 2019 who found that the competence of village officials had an effect toward the accountability of managing village fund allocations. In line with research by Subroto (2009), it found that the inhibiting factor for managing village fund allocations was the low competence of village government officials. Low competency in human resources and ineffective monitoring and evaluation made a difference in the management of village fund allocations. As a result, management accountability for village fund allocation does not reflect accountable management. This research was also in line Putra and Rasmini (2019), Zirman et al. (2010), Tarjo (2019), it found that the competence of village officials had an effect toward village fund accountability. It was in line with agency theory which explains that there is a relationship between agents and principals to carry out a service in making decisions.

In this case, the central government provides the mandate to manage the allocation of village funds in the village government. In managing village government, it must be based on regulations and regulations stipulated by Law No. 6 Year 2014 concerning villages and Minister of Home Affairs and regulation No. 113 of 2014 concerning financial management of village funds. In the context of Bogor District, the competence of the instructors in managing village allocation funds had good competence. It haf been supported with expertise and skills. Village officials were able to understand the main tasks, planning village financial budgeting and they were able to make village financial reports in accordance with applicable norms or rules. The competence of village officials is an important factor considering competence as an internal factor and becomes an important factor.

The Effect of Society Participation on Accountability of Village Fund Allocation Management: Test toward first hypothesis showed the effect of the variable implementation of government accounting standards on the quality of government financial statement information. After conducting the statistical $t$ test, it was obtained a tcount of -.391 with t-table of 1.992 . Thus, tcount <t table $(-, 391<1.993)$ with a significance level of more than $0.05(0.697>0.05)$. Thus, H0 was accepted. It can be concluded that the independent variable of community participation does not significantly affect the accountability of village fund allocation management. Hopefully, the supervision from a qualified BPD will affect the accountability of village fund allocation management. This research was not in line with research conducted by by Putra and Rasmini (2019) because there was an influence of community participation with accountability in the management of village fund allocation in Badung Regency.

Besides, it was not inline with Umaira and Adnan's research (2019) which examined the accountability of village fund management in Southwest Aceh District was affected by community participation. The findings were not in line with Naimah (2017) which found accountability in the management of village fund allocations that was not affected by community participation. Community participation can lead to good governance because the absence of restrictions between the government and the community can make local officials more responsible (Kim \& Schachter, 2013). This research did not support theory which states that development programs that were given power to the community by the government at the community level must be implemented properly. One level of community participation is consultation related to being notified of invitations to give various opinions. Yet, there is no guarantee that the opinion will be considered in decision making.

The Effect of Supervision on Accountability of Village Fund Allocation Management: Test toward second hypothesis showed variable effect of the use of information technology on the quality of information of government financial statements. After conducting the statistical t-test, it was obtained a tcount of 1.751 with a table of 1.993 . Thus, the tcount <t table $1.751<1.993$ ) with a significance level of more than $0.084(0.084>0.05)$, thus, H0 was accepted. It can be concluded that supervision has no significant effect on village fund management accountability. This study in line with Munti and Fahlevi (2017) who supervise BPD are also the opposite of Atmadja and Saputra (2018) and Triyono, Achyani and Arfiansyah, (2019). The results of the research have shown that monitoring supervision affects accountability in the management of village fund allocations. Supervision quality did not give effect toward village fund allocation management accountability because supervision was better. It did not affect the accountability of village fund allocation management.

The Village Supervisory Agency (VSA) rights are regulated in Permendagri Number 110 Year 2016 including monitoring and evaluating the productivity of village heads; ask for clarification about village governance from the village government. This privilege is supported by a regional regulation on the Village Consultative Body (village council) which gives this council to control and request clarification on 
village governance from the village government.It means that the qualification of the control function has not yet been reached and it is effective. Supporting factors do not effectively follow the agenda to control results. VSA has a strong protection. Thus, it can conduct well control function and it had a trusted quality supervision. It is because the BPD has good quality in the supervision system for the village program, the village government can carry out the village development program in accordance with the village specific work plan (Village RKP).

\section{Conclusion}

The aim of this research is to examine and analyze the influence of the competence of village officials, Society participation and supervision of the accountability of village fund allocation management. Based on the findings and research discussion, it can be concluded that the competence of village officials has a significant effect on the accountability of village fund allocation management. This shows that village fund managers continue to be given guidance from the sub-district and district governments on managing village funds continuously. Thus, they can master village financial management well. In addition, participation of society, supervision do not significantly affect the accountability of village fund allocation management. This is generally due to the limited delivery of information by village officials, the lack of socialization to the community. This is because the qualification of the supervisory function has not yet been achieved and it is effective. There is no standard control system from the VSA in controlling the productivity of the village head, and the planning is not sustainable by the VSA. Furthermore, the researcher adds other variables such as the accessibility of financial reports, the quality of supervision by the Village Council, and the financial funding system. Research data collection must be complemented using interview methods to dig deeper into village fund management. Besides, further research is expected to expand research..

\section{References}

Aikins, S. K. (2011). An examination of government internal audit's role in improving financial performance. Journal of Public Finance and Management, 11(4), 306-337.

Anugriani, R. M. (2014). Pengaruh akuntabilitas, transparansi, dan pengawasan terhadap kinerja anggaran berkonsep value for money pada instansi pemerintah di Kabupaten Bone. Skripsi. Jurusan Akuntansi Fakultas Ekonomi dan Bisnis Universitas Hasanuddin Makassar.

Aziz, N. L. L. (2016). Otonomi desa dan efektivitas dana desa. Jurnal Penelitian Politik, 13(2), 193-211.

Aziiz, M. N. \& Prastiti, S. D. (2019). Faktor-faktor yang memperngaruhi akuntabilitas dana desa. Jurnal Akuntansi Aktual, 6(2), 280-344.

Atmadja, A. T. \& Saputra, K. A. K. (2018). Determinant Factors Influencing the Accountability of Village Financial Management. Academy of Strategic Management Journal, 17(1), 1-9.

Budiana, D. A., Said, D. \& Nursini. (2019). The effect of village device competencies and internal control system on accountability of village management. Scientific Research Journal, 7(1), 10-20.

Cheng, R. H., Engstrom, J. H. \& Kattelus, S. C. (2002). Educating government financial managers: University collaboration between business and public administration. The Journal of Government Financial Management, 51(3), 10-15.

Dewi, N. K. \& Gayatri, A. J. P. (2019). Faktor-faktor yang berpengaruh pada akuntabilitas pengelolaan alokasi dana desa. E-Jurnal Akuntansi Universitas Udayana, 26(2), 1269-1298.

Faristina, R. (2011). Faktor-faktor yang mempengaruhi keandalan dan timeliness pelaporan keuangan badan layanan umum (Studi pada BLU di Kota Semarang). Skripsi Universitas Diponegoro: Semarang.

Homayoun, S. (2015). Agency theory and corporate governance. International Business Management, 9(5), 805-815.

Indrajaya J. A. (2017). Pengaruh kompetensi aparatur desa dan implementasi Undang-Undang No 6 Tahun 2014 terhadap pengelolaan keuangan dana desa. Skripsi. Universitas Lampung. Lampung.

Kim, S. \& Schachter, H. L. (2013). Citizen participation in the budget process and local government accountability. Case studies of organizational learning from the United States and South Korea. Public Performance and Management Review, 36(3), 456-471.

Kompas.com Sejak tahun (2015 -2018). Kasus korupsi Dana desa terus mengalami peningkatan dari tahun ketahun.

Mada, S., Lintje, K. \& Gamaliel, H. (2017). Pengaruh kompetensi aparat pengelola Dana desa, komitmen organisasi pemerintah desa, dan partisipasi masyarakat terhadap akuntabilitas pengelolaan Dana desa di Kabupaten Gorontalo. Jurnal Riset Akuntansi dan Auditing, (8), 106-115. 
Munti, F. \& Fahlevi, H. (2017). Determinan Kinerja Pengelolaan Keuangan Desa: Studi pada Kecamatan Gandapura Kabupaten Bireuen Aceh. Jurnal Akuntansi dan Investasi, 18(2), 172-182.

Naimah. (2017). Faktor-faktor yang mempengaruhi akuntabilitas keuangan desa pada pemerintah kabupaten serdang bedagai. Tesis Magister Jurusan Akuntansi pada Fakultas Ekonomi Dan Bisnis Universitas Sumatera Utara, Medan.

Nurjaman, R. (2015). Dinamika dan problematika implementasi uu desa: pembelajaran dari 2 daerah di jawa barat. Jurnal Desentralisasi, 13(1), 47-60.

Panda, B. \& Leepsa, N. M. (2017). Agency theory: Review of theory and evidence on problems and perspectives. Indian Journal of Corporate Governance, 10(1), 74-95.

Pepper, A. \& Gore, J. (2015). Behavioral agency theory: new foundations for theorizing about executive compensation, (March).

Permendagri, 20. (2018). Pengelolaan Dana desa yang dilaksanakan oleh perangkat desa diharapkan dapat mewujudkan kesejahteraan masyarakat dan mempercepat pembangunan desa.

Putra, I. Y. D. \& Rasmini, N. K. (2019). Pengaruh akuntabilitas, transparansi, dan partisipasi masyarakat pada efektivitas pengelolaan Dana desa, E-Jurnal Akuntansi, 28(1), 132-158.

Santoso, E. B. (2016). Pengaruh sistem pengendalian intern pemerintah, pemanfaatan teknologi informasi dan kompetensi sumber daya manusia terhadap akuntabilitas keuangan daerah (studi empiris pada pemeritah kabupaten lampung timur). Tesis, Universitas Lampung.

Sekaran, U. \& Bougie, R. (2013). Research methods for business: A skill building approach (6th ed.). United Kingdom: John Wiley \& Sons.

Siagian, S. P. (2002). Fungsi-Fungsi Manajerial. Jakarta: Rineka Cipta.

Umaira, S. \& Adnan. (2019). Pengaruh partisipasi masyarkat, kompetensi sumber daya manusia, dan pengawasan terhadap akuntabilitas pengelolaan dana desa (studi kasus padan kabupaten aceh barat daya). Jurnal Ilmiah Mahasiswa Ekonomi Akunansi, 4(3), 471-481.

Subroto, A. (2009). Akuntabilitas pengelolaan alokasi dana desa (studi kasus pengelolaan alokasi dana desa di desa - desa dalam wilayah Kecamatan Tlogomulyo Kabupaten Temanggung tahun 2008). Dipublikasikan. Tesis. Program Studi Magister Sains Akuntansi. Universitas Diponegoro Semarang.

Sujarweni, V. W. (2015). Akuntansi Desa: panduan tata kelola keuangan desa. Yogyakarta: Pustaka Baru Press.

Tarjo. (2019). Pengaruh kompetensi apparat desa dan komitmen organisasi terhadap akuntabilitas dana desa (studi pada desa muara niro kecamatan VII Kota kabupaten tabo). Jurnal Tata Sejuta, 5(2), 1-16.

Thomas. (2013). Pengelolaan alokasi dana desa dalam upaya meningkatkan pembangunan di desa sebawang kecamatan sesayap kabupaten tana tuding. Journal Pemerintahan Integratif, 1(1), 5164.

Triyono, A., F. \& Arfiansyah, M. A. (2019). The terminant accountability of village funds management (Study in the village in Wonogiri district). Riset Akuntansi dan Keuangan Indonesia, 4(2), 118-135.

Undang-Undang (UU) Nomor 5 Tahun. (1979). Tentang pemerintahan desa yang secara faktual dan empiris telah mengatur otonomi Desa.

Undang-Undang (UU) Nomor 6 Tahun. (2014). Tentang desa, yang dimana desa memiliki hak-haknya dalam mengatur dan mengurus kepentingan masyarakat setempat dan berperan dalam mewujudkan cita-cita kemerdekaan.

Widyatama, A., Novita, L. \& Diarespati. (2017). Pengaruh kompetensi dan sistem pengendalian internal terhadap akuntabilitas pemerintah desa dalam mengelola Alokasi Dana Desa (ADD). Berkala Akuntansi dan Keuangan Indonesia, 2(2), 1-21.

Yamin, M. \& Ishak. (2018). The effect of employees competency, application of performance-based budgeting and functional supervision on the performance (LKPD) SKPD". International Journal of Scientific \& Technology Research, 7(8), 215-219.

Zirman, Edvan. \& Rozi. (2010). Pengaruh kompetensi aparatur pemerintah daerah, penerapan akuntabilitas keuangan, motivasi kerja dan ketaatan pada peraturan perundangan terhadap akuntabilitas kinerja instansi pemerintah. Jurnal Ekonomi, 18, 1-21. 